\title{
STRUKTUR KOMUNITAS MANGROVE DI DESA MOJO KABUPATEN PEMALANG JAWA TENGAH
}

\author{
Oleh \\ Person Pesona Renta ${ }^{1 *}$, Rudhi Pribadi $^{2}$, Muhammad Zainuri ${ }^{2}$, Maya Angraini \\ Fajar Utami ${ }^{1}$ \\ ${ }^{1}$ Program Studi IImu Kelautan Fakultas Pertanian Universitas Bengkulu, Bengkulu \\ 2Jurusan IImu Kelautan Fakultas Perikanan dan IImu Kelautan Universitas Diponegoro \\ Email : personpesona@gmail.com \\ Received July 2016, Accepted August 2016
}

\begin{abstract}
ABSTRAK
Pengelolaan ekosistem mangrove dalam menunjang ekonomi masyarakat pesisir dewasa ini menjadi penting dan menjadi sebuah perhatian khusus dikarenakan oleh fungsi dan peran hutan mangrove yang beraneka ragam. Ekosistem Mangrove di Desa Mojo mengalami perubahan luasan dikarenakan kegiatan rehabilitasi, faktor alam dan faktor manusia seperti pemukiman, tambak, dan penggunaan lainnya. Penelitian ini bertujuan untuk mengetahui jenis-jenis mangrove dan struktur vegetasi di ekosistem mangrove Desa Mojo, Kabupaten Pemalang.

Penelitian ini dilakukan dengan menggunakan metode purposif (Purposive Sampling Method) dengan metode sample plot untuk pengamatan struktur dan komposisi vegetasi mangrove. Hasil penelitian menunjukkan bahwa ditemukan 3 spesies mangrove yaitu jenis Avicenia marina, Avicenia alba, Rhizopora mucronata. Kondisi vegetasi mangrove di Desa Mojo pada tingkat pohon didominasi oleh Avicenia marina dengan Indeks Nilai Penting (INP) sebesar 153.24, vegetasi mangrove pada tingkat anakan didominasi oleh Rhizophora mucronata dengan Indeks Nilai Penting (INP) sebesar 171,404 sedangkan pada tingkat semai tidak ditemukan mangrove di dalam transek.
\end{abstract}

Kata kunci : mangrove, struktur komunitas, analisis vegetasi, desa mojo 


\section{PENDAHULUAN}

\section{Latar Belakang}

Ekosistem mangrove merupakan tipe vegetasi khas yang terdapat di daerah pantai tropis. Vegetasi mangrove umumnya tumbuh subur di daerah pantai yang landai di dekat muara sungai dan pantai yang terlindung dari kekuatan gelombang. Ekosistem hutan mangrove bersifat kompleks dan dinamis, namun labil. Ekosistem hutan mangrove merupakan daerah asuhan (nursery ground) hewan-hewan muda (juvenile stage) yang akan bertumbuh kembang menjadi hewan-hewan dewasa dan juga merupakan daerah pemijahan (spawning ground) beberapa satwa dan biota perairan seperti burung, serangga, ular, udang, ikan dan kerang-kerangan (Dahuri, 2002).

Desa Mojo, Kecamatan Ulujami, Kabupaten Pemalang, Jawa Tengah memiliki hutan mangrove seluas 72 ha, merupakan keberhasilan program rehabilitasi mangrove yang dilaksanakan atas kerjasama antara OISCA dengan Pemerintah Kabupaten Pemalang bersama kelompok masyarakat Pelita Bahari yang disponsori oleh Tokio Marine Insurance dengan nama program Tokio Marine Mangrove Program. Mangrove di Desa Mojo dikelola oleh kelompok Pelita Bahari dan telah memperoleh izin pengelolaan dari Bupati Kabupaten Pemalang sejak tahun 2008. Gangguan terhadap tanaman mangrove di Desa Mojo disebabkan oleh abrasi dan sedimentasi. Faktor manusia yang mencari makanan ternak di sekitar mangrove juga menjadi gangguan bagi ekosistem mangrove. Kawasan hutan mangrove mengalami penambahan luasan disebabkan oleh kegiatan rehabilitasi namun juga mengalami pengurangan luasan akibat faktor alam dan manusia, Hal ini meyebabkan perubahan terhadap fungsi mangrove sehingga perlu untuk mengetahui vegetasi dan struktur komunitas hutan mangrove di Desa Mojo Kabupaten Pemalang sehingga dapat menjadi dasar kebijakan pengelolaan mangrove secara berkelanjutan.

\section{Tujuan}

Tujuan penelitian ini yaitu untuk mengetahui jenis-jenis mangrove dan struktur vegetasi di hutan mangrove Desa Mojo, Kabupaten Pemalang.

\section{METODE PENELITIAN}

\section{Tempat dan Waktu Penelitian}

Penelitian ini dilaksanakan di Desa Mojo, Kabupaten Pemalang, Provinsi Jawa Tengah. Penelitian dilaksanakan dalam dua tahap yaitu tahap pertama adalah penelitian pendahuluan yang dilaksanakan pada Bulan September Oktober 2011. Sedangkan penelitian lanjutan dilaksanakan pada Bulan Juli Agustus 2012.

\section{Alat dan Bahan} Tabel 1.

Alat dan bahan yang digunakan selama penelitian dapat di lihat pada Tabel 1. Alat dan bahan yang digunakan dalam penelitian

\begin{tabular}{cll}
\hline No & Alat/Bahan & Kegunaan \\
\hline 1 & 1 rol tali $40 \mathrm{~m}$ & Untuk transek $10 \times 10 \mathrm{~m}$ (sampel pohon) \\
2 & 1 rol tali $10 \mathrm{~m}$ & Untuk transek $5 \times 5 \mathrm{~m}$ (sampel anakan) \\
3 & 1 rol tali $2 \mathrm{~m}$ & Untuk transek $1 \times 1 \mathrm{~m}$ (sampel semai) \\
4 & Jangka sorong & Mengukur diameter batang
\end{tabular}




\begin{tabular}{cll}
5 & Termometer & Mengukur suhu \\
6 & Refraktometer & Mengukur salinitas \\
7 & Kertas Ph & Mengukur $\mathrm{pH}$ \\
8 & Gunting/pisau & Memotong ranting untuk sampel \\
9 & Kantong plastic & Wadah herbarium dan sampel sedimen \\
10 & GPS & Menentukan titik koordinat stasiun \\
11 & Kamera dgital & Mengambil dokumentasi \\
12 & Alat tulis & Mencatat data lapangan \\
13 & Buku identifikasi mangrove & Mengidentifikasi spesies mangrove \\
\hline
\end{tabular}

\section{Penentuan Lokasi Penelitian}

Penentuan titik sampling dalam penelitian ini dilakukan dengan menggunakan metode purposif (Purposive Sampling Method). Metode ini merupakan metode pengambilan sampel yang dilakukan dengan mengambil subyek bukan didasarkan atas strata, random atau daerah, tetapi didasarkan atas tujuan tertentu. Teknik ini biasanya dilakukan karena beberapa pertimbangan, misalnya alasan keterbatasan waktu, tenaga dan dana, namun harus tetap memperhatikan syarat-syarat yang harus dipenuhi misalnya subyek yang diambil sebagai sampel benar-benar merupakan subjek yang paling banyak mengandung ciri-ciri yang terdapat pada populasi (key subjectis) (Arikunto, 2010). Dalam penelitian ini lokasi sampling ditentukan berdasarkan keberadaan vegetasi mangrove.

\section{Kualitas Perairan}

Parameter kualitas air yang diukur antara lain : suhu diukur dengan menggunakan thermometer, salinitas diukur dengan refraktometer, dan derajat keasaman $(\mathrm{pH})$ dikur dengan kertas $\mathrm{pH}$. Kualitas perairan sangat mempengaruhi struktur, fungsi, komposisi dan pola pertumbuhan mangrove, oleh karena itu pengukuran pengukuran parameter kualitas air sangat diperlukan untuk mengetahui kesesuaiannya untuk mangrove di lokasi penelitian.

\section{Kondisi Oseanografis dan Curah Hujan}

Kondisi oseanografis merupakan salah satu faktor yang menentukan keberhasilan suatu program rehabilitasi mangrove yaitu mempengaruhi kelulushidupan tanaman mangrove. Data oseanografis yang diperlukan meliputi data arus, gelombang dan pasang surut. Data oseanografis dan data curah hujan diperoleh dari data sekunder dari laporan DKP Jawa Tengah mengenai Identifikasi Kerusakan dan Perencanaan Rehabilitasi Pantura Jawa Tengah tahun 2011.

\section{Tekstur Tanah}

Data tekstur tanah diperoleh dari data sekunder laporan DKP Jawa Tengah mengenai Identifikasi Kerusakan dan Perencanaan Rehabilitasi Pantura Jawa Tengah tahun 2011.

\section{Struktur dan Komposisi Vegetasi Mangrove}

Pengamatan struktur dan komposisi vegetasi mangrove dilakukan dengan dengan menggunakan metode sample plot yang merupakan modifikasi dari cara yang digunakan oleh Mueller Dumbois and Ellenberg (1974). Masingmasing stasiun penelitian terdapat 3 plot yang berukuran $10 \times 10 \mathrm{~m}$. Di dalam 
masing-masing plot 10×10 m dibuat plot yang lebih kecil dengan ukuran $5 \times 5 \mathrm{~m}$, dan di dalam masing-masing plot $5 \times 5 \mathrm{~m}$ dibuat plot yang berukuran $1 \times 1 \mathrm{~m}$. Masing-masing plot mempunyai fungsi yang berbeda. Plot $10 \times 10 \mathrm{~m}$ digunakan untuk pengambilan data pohon (tree) dengan diameter batang pohon $\geq 4 \mathrm{~cm}$. Plot $5 \times 5 \mathrm{~m}$ digunakan untuk pengambilan data anakan (sapling) dengan diameter antara 1-4 cm $(1 \mathrm{~cm} \leq$ diameter batang pohon $<4 \mathrm{~cm})$ dan tinggi $>1 \mathrm{~m}$. Sedangkan plot yang berukuran $1 \times 1 \mathrm{~m}$ digunakan untuk pengambilan data semai (seedling) dengan ketinggian $<1 \mathrm{~m}$.

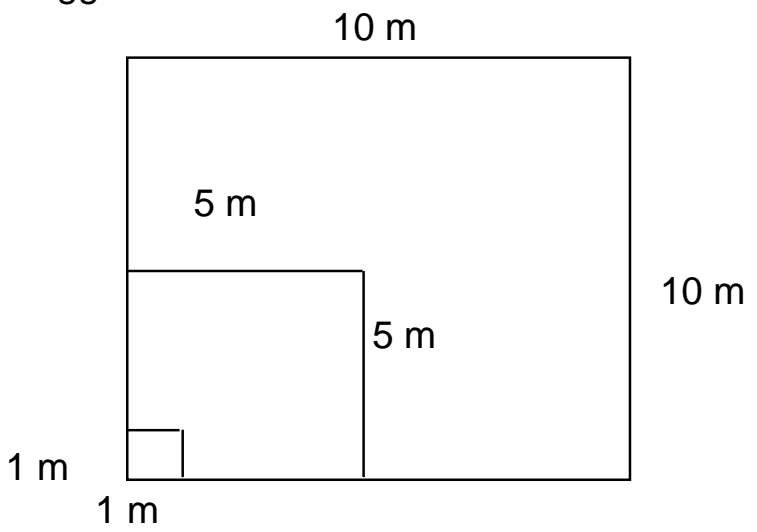

Gambar 1. Peletakan sub plot $1 \mathrm{~m} \times 1 \mathrm{~m}$ (seedling) dan sub plot $5 \mathrm{~m} \times 5 \mathrm{~m}$ (sapling) dalam plot $10 \mathrm{~m} \times 10 \mathrm{~m}$ (pohon) untuk vegetasi mangrove pada transek penelitian.

\section{Data Kondisi Fisik Mangrove}

\section{ANALISIS DATA}

Data-data yang diperoleh dari observasi lapangan maupun data-data pelengkap akan dianalisis secara deskriptif untuk menggambarkan kondisi mangrove saat ini dan upaya rehabilitasi yang sudah dilakukan. Selain itu dilakukan juga analisis berupa interpretasi data dengan bantuan data sekunder yang diuraikan dalam bentuk diagram atau tabel sehingga bisa menghasilkan uraian yang terperinci. Analisis data vegetasi mangrove dilakukan untuk mengetahui nilai Kerapatan (K), Basal Area (BA), Kerapatan Relatif (KR), Dominasi Relatif (DR), Nilai Penting (NP), Indeks Keanekaragaman ( $\left.\mathrm{H}^{\prime}\right)$ dan Indeks Keseragaman (J') dengan rumus masing-masing sebagai berikut :

\section{Kerapatan (K)}

Kerapatan adalah jumlah individu per unit area (Cintron and Novelli, 1984). Satuan dari kerapatan dalam penelitian ini adalah individu per hektar (ind/ha).

$$
\mathrm{K}(\text { spesies } \mathrm{A})=\frac{\text { Jumlah individu spesies A }}{\text { Luas area transek }(\mathrm{ha})}
$$

\section{Basal Area (BA)}

Basal area merupakan penutupan areal hutan mangrove oleh batang pohon. Basal area didapatkan dari pengukuran batang pohon mangrove yang diukur secara melintang (Cintron dan Novelli, 1984). Diameter batang tiap spesies tersebut kemudian diubah menjadi basal area dengan menggunakan rumus :

$$
B A=\frac{\pi \cdot D^{2}}{4} \mathrm{~cm}^{2}
$$




$$
\begin{array}{ll}
\text { dimana, } & \mathrm{BA} \\
\mathrm{T} & =3.14 \\
\mathrm{D} & =\text { Diameter batang }
\end{array}
$$

\section{Kerapatan Relatif (KR)}

Kerapatan Relatif merupakan prosentase kerapatan spesies dalam transek. Nilai kerapatan Relatif didapatkan dengan rumus (English et al., 1997) :

$$
\begin{aligned}
& \text { KR }(\text { spesies } A)=100 \% \times(\mathrm{ni} / \mathrm{N}) \\
& \text { dimana, } \quad \mathrm{KR}=\text { Kerapatan Relatif } \\
& \mathrm{ni}= \text { Jumlah individu spesies } \mathrm{A} \\
& \mathrm{N}=\text { Jumlah total individu seluruh spesies }
\end{aligned}
$$

\section{Dominansi Relatif (DR)}

Dominansi relatif merupakan presentase penutupan suatu spesies terhadap suatu areal yang didapatkan dari nilai basal area untuk spesies pohon dan sapling dengan menggunakan rumus (English et al., 1997) :

$$
\mathrm{DR}=\frac{\mathrm{BAi}}{\mathrm{BA}} \times 100 \%
$$

dimana, $\quad$ DR $=$ Dominansi Relatif

$\mathrm{BAi}=$ Basal area tiap spesies

$\mathrm{BA}=$ Jumlah total basal area

Untuk kategori seedling, perhitungan DR menggunakan rumus :

$$
\begin{aligned}
& \text { DR }= 100 \%(\text { Coi } / \text { Co }) \\
& \text { dimana, } \quad \begin{aligned}
\text { DR } & =\text { Dominansi relatif } \\
\text { Coi }=\text { Rata-rata nilai tengah prosentase penutupan tiap } & \text { spesies } \mathrm{i} \\
\text { Co } & =\text { Total prosentase penutupan dari semua spesies }
\end{aligned}
\end{aligned}
$$

\section{Nilai Penting (NP)}

Nilai penting diperoleh untuk mengetahui tingkat dominasi suatu spesies pada suatu areal. Nilai penting ini didapat dengan menjumlahkan nilai kerapatan relatif dan dominansi relatif (Curtis, 1959) :

$$
\begin{aligned}
N P=K R & +D R \\
\text { dimana, } \quad \mathrm{NP} & =\text { Nilai Penting } \\
\mathrm{KR} & =\text { Kerapatan Relatif } \\
\mathrm{DR} & =\text { Dominansi Relatif }
\end{aligned}
$$

\section{Indeks Keanekaragaman (H')}

Indeks Keanekaragaman merupakan karakteristik dari suatu komunitas yang menggambarkan tingkat keanekaragaman spesies dari organisme yang terdapat dalam komunitas tersebut (Odum, 1993). Rumusnya adalah : 


$$
\begin{aligned}
& \mathrm{H}^{\prime}=\log \mathrm{N}-\frac{1}{N} \Sigma \mathrm{ni} \log \mathrm{ni} \\
& \text { dimana, } \quad \mathrm{H}^{\prime} \quad=\text { Indeks Keanekaragaman Shannon } \\
& n i \quad=\text { Jumlah individu spesies ke-i } \\
& \mathrm{N} \quad=\text { Jumlah total individu seluruh spesies }
\end{aligned}
$$

Menurut Wilhm dan Dorris (1986), klasifikasi indeks keanekaragaman Shannon-Weaver adalah sebagai berikut :

$$
\begin{array}{ll}
H^{\prime}<1 & =\text { Indeks Keanekaragaman rendah } \\
1 \leq H^{\prime} \leq 3 & =\text { Indeks Keanekaragaman sedang } \\
H^{\prime}>3 & =\text { Indeks Keanekaragaman tinggi }
\end{array}
$$

\section{Indeks Keseragaman ( $\left.\mathrm{J}^{\prime}\right)$}

Indeks Keseragaman spesies merupakan perbandingan antara nilai keanekaragaman dengan Logaritma natural dari jumlah spesies (Odum, 1993), rumusnya:

$$
\begin{array}{rll} 
& \mathrm{J}^{\prime}= & \frac{H^{\prime}}{\operatorname{Ln}(S)} \\
& & \\
\text { dimana, } & \mathrm{J}^{\prime} & =\text { Indeks Keseragaman spesies } \\
& \mathrm{H}^{\prime} & =\text { Indeks Keanekaragaman Shannon } \\
\mathrm{S} & \text { = Jumlah spesies }
\end{array}
$$

Krebs (1989) menyatakan besarnya indeks keseragaman spesies berkisar antara $0-1$, dimana:

$$
\begin{aligned}
& \mathrm{J}^{\prime} \geq 0,6=\text { Keseragaman spesies tinggi } \\
& 0,4<\mathrm{J}^{\prime}<0,6=\text { Keseragaman spesies sedang } \\
& \mathrm{J}^{\prime} \leq 0,4=\text { Keseragaman spesies rendah }
\end{aligned}
$$

Indeks Dominansi (D)

Indeks dominansi merupakan derajat pada dominansi dari satu, beberapa atau banyak spesies (Odum, 1993). Metode penghitungan yang digunakan adalah rumus Indeks Dominansi Simpson (Simpson, 1949 dalam Odum, 1993) yaitu;

$$
\begin{aligned}
& \mathrm{D}=\Sigma(\mathrm{ni} / \mathrm{N})^{2} \\
& \text { dimana: } \quad \mathrm{D}=\text { Indeks dominansi } \\
& \mathrm{ni}=\text { Jumlah individu spesies ke-i } \\
& \mathrm{N}=\text { Jumlah total individu }
\end{aligned}
$$

Kriteria Indeks Dominansi menurut Simpson (1949) dalam Odum (1993):

$0<\mathrm{D}<0,5 \quad$ : Tidak ada spesies yang mendominasi

$0,5<\mathrm{D}<1 \quad$ : Terdapat spesies yang mendominasi

\section{HASIL DAN PEMBAHASAN}

\section{Kualitas Perariran}

Kisaran salinitas yang teramati pada saat penelitian sebesar 35-40 ppt. Salinitas merupakan gambaran jumlah garam dalam suatu perairan (Dahuri et al., 2004). Kusmana et al. (2003) menyatakan bahwa spesies A. marina, Rhizophora sp., Sonneratia sp., E. agallocha, L. racemosa, dan C. tagal dapat tumbuh dengan baik pada kisaran salinitas 10-30 ppt. Meskipun demikian dengan kisaran salinitas yang teramati, mangrove di lokasi masih dapat tumbuh hal ini dikarenakan pada saat pengamatan kondisi perairan sedang surut. Nontji 
(2005) menyatakan bahwa sebaran salinitas di air laut dipengaruhi oleh berbagai faktor seperti pola sirkulasi air, penguapan, curah hujan dan aliran sungai. Selain salinitas, suhu air juga merupakan faktor penting yang menentukan kehidupan tumbuhan mangrove. Suhu perairan yang teramati pada saat penelitian berkisar $24-30^{\circ} \mathrm{C}$, hal ini sesuai dengan pernyataan Kennish (1990) dan Supriharyono (2007) bahwa mangrove dapat tumbuh dengan subur di daerah tropis pada kisaran suhu lebih dari $20^{\circ} \mathrm{C}$.

\section{Kondisi Oseanografis dan Curah Hujan}

Pasang surut di lokasi penelitian merupakan tipe pasang surut campuran condong harian tunggal dimana penggenangan 1-2 kali dalam sehari atau minimal 20 hari dalam sebulan dengan julat pasang mencapai $1 \mathrm{~m}$. Curah hujan di Desa Mojo sebesar $1.943 \mathrm{~mm} / \mathrm{th}$, hal ini sesuai dengan pernyataan Aksornkoae (1993) bahwa pada umumnya tumbuhan mangrove tumbuh dengan baik pada daerah dengan rata-rata curah hujan 1500-3000 mm/th.

\section{Teksur Tanah}

Tekstur tanah Desa Mojo adalah lempung (DKP Jateng,2011). Kusmana et al. (2003) menyatakan bahwa tekstur tanah tersebut sesuai untuk jenis mangrove Avicenia sp., Rhizophora sp., Sonneratia sp., E. agallocha, L. racemosa, dan Ceriops sp.

\section{Struktur dan Komposisi Ekosistem Mangrove}

Ekosistem mangrove di Desa Mojo merupakan hasil penanaman kembali oleh kelompok tani tambak yang sekaligus mengelola mangrove. Penanaman tersebut dilakukan dengan tujuan untuk melindungi tambak-tambak penduduk dari gempuran ombak. Pada saat sampling menggunakan transek sepanjang 3 kali 100 m diketahui bahwa jenis yang temui adalah Avecennia marina, Avicennia alba dan Rhizopora mucronata.

Perhitungan analisis vegetasi mangrove tersebut dikelompokkan ke dalam tiga kategori yaitu kategori pohon (tree), kategori anakan (Sapling), dan kategori semai (seedling).

a. Kategori Pohon (Tree)

Hasil struktur komposisi mangrove untuk kategori pohon dapat dilihat pada tabel 2.

Tabel 2 . Struktur Komposisi Vegetasi Mangrove Kategori Pohon (Tree) di Desa Mojo, Kabupaten Pemalang

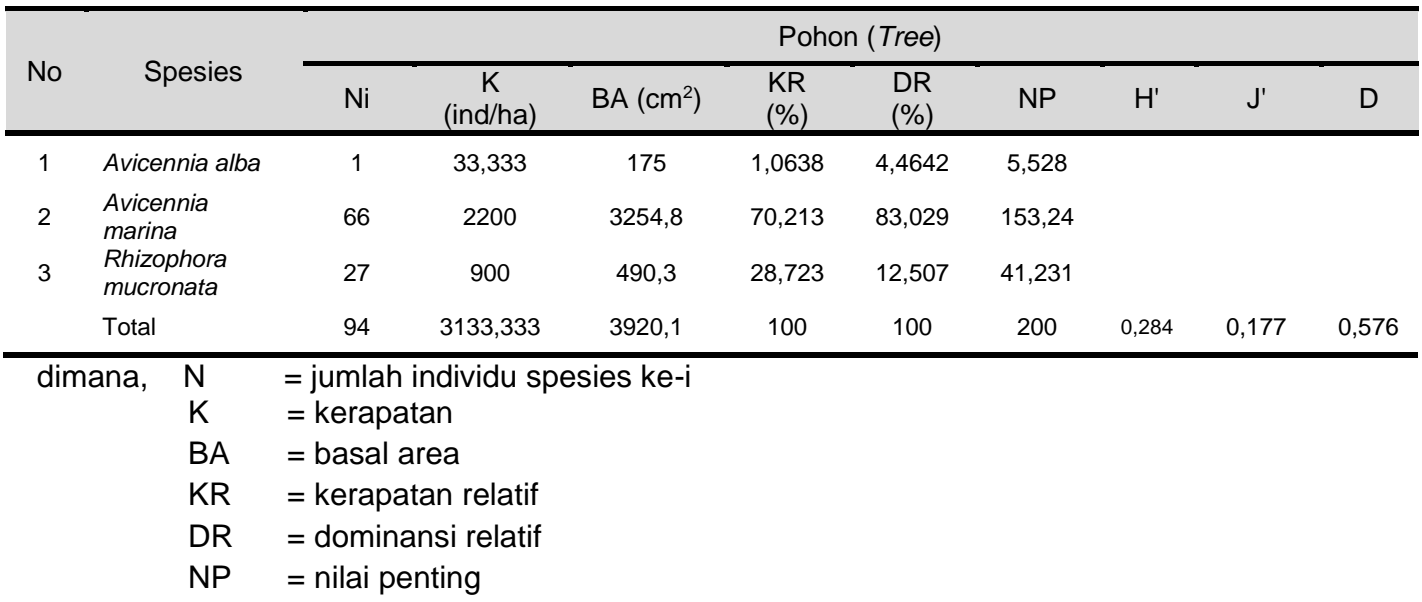




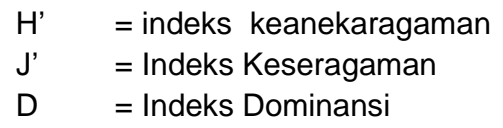

Kerapatan $(\mathrm{K})$ vegetasi mangrove di Desa Mojo pada kategori pohon (tree) adalah 3133,333 ind/ha, dimana kerapatan tertinggi dimiliki oleh jenis $A$. marina dengan nilai 2200 ind/ha dengan kerapatan relatif (KR) 70,213\%. Sedangkan kerapatan terendah dimiliki oleh jenis $A$. alba (33,33 ind/ha) dengan kerapatan relatif $1,0638 \%$. Sama seperti nilai KR, nilai dominasi relatif (DR) tertinggi juga dimiliki oleh jenis $A$. marina yaitu $83,029 \%$ dan nilai DR terendah juga dimiliki oleh jenis $A$. alba yaitu $12,507 \%$.

Indeks Keanekaragaman $\left(\mathrm{H}^{\prime}\right)$ vegetasi mangrove di Desa Mojo pada kategori pohon adalah 0,284 . Sedangkan nilai Indeks Keseragamannya (J') adalah 0,177 . Sementara itu, Nilai Penting (NP) tertinggi pada kategori pohon dari 3 jenis mangrove yang ditemukan adalah jenis $A$. marina dengan nilai $153,24 \%$ dan nilai terendah adalah jenis $A$. alba dengan nilai $5,528 \%$.

\section{b. Kategori Anakan (Sapling)}

Hasil struktur komposisi mangrove untuk kategori anakan (sapling) dapat dilihat pada tabel 3 .

Tabel 3. Struktur Komposisi Vegetasi Mangrove Kategori Anakan (Sapling) di Desa Mojo, Kabupaten Pemalang

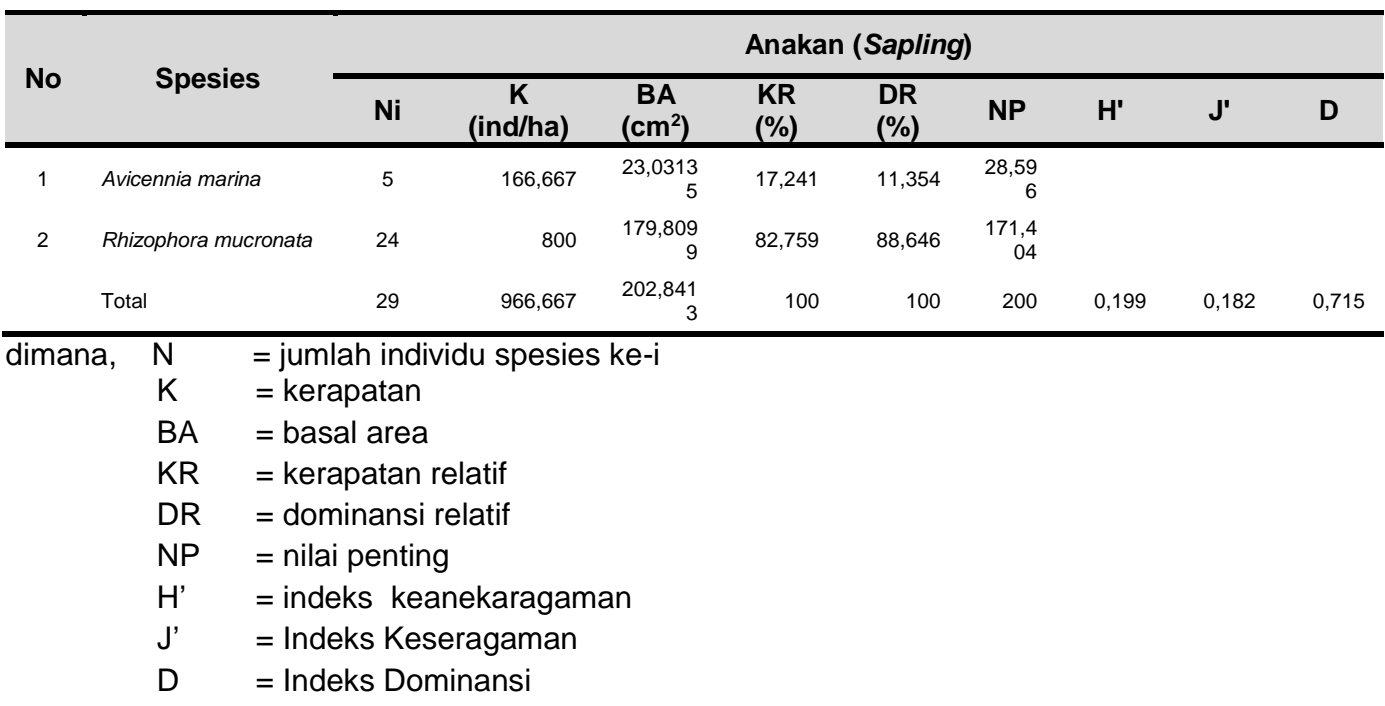

Kerapatan $(\mathrm{K})$ vegetasi mangrove di Desa Mojo pada kategori anakan (Sapling) adalah 966,667 ind/ha, dimana kerapatan tertinggi dimiliki oleh jenis $R$. mucronata (800 ind/ha) dengan kerapatan relatif (KR) $82,759 \%$. Sedangkan kerapatan terendah dimiliki oleh jenis $A$. marina $(166,67$ ind/ha) dengan kerapatan relatif $(K R) 17,241 \%$. Nilai dominasi relatif (DR) tertinggi juga dimiliki oleh jenis $R$. mucronata yaitu $88,646 \%$ sedangkan DR terendah dimiliki oleh jenis A. marina yaitu $11,354 \%$.

Indeks Keanekaragaman $\left(\mathrm{H}^{\prime}\right)$ vegetasi mangrove di Desa Mojo pada kategori sapling adalah 0,199. Sedangkan Indeks Keseragamannya (J') adalah 0,182 . Sementara itu, Nilai Penting (NP) tertinggi dimiliki oleh $R$. mucronata yaitu $171,404 \%$ dan NP terendah dimiliki oleh jenis $A$. marina dengan nilai $28,596 \%$. 


\section{c. Kategori Semai (Seedling)}

Kategori semai (seedling) tidak ditemukan di Desa Mojo sehingga tidak dapat dihitung nilai struktur komposisi vegetasi mangrove. Kondisi mangrove saat ini di Desa Mojo tergolong sudah baik karena sudah menyerupai hutan kembali, sedangkan di Desa Klidang Lor kondisinya rusak akibat abrasi. Luas hutan mangrove di Desa Klidang Lor saat ini kurang lebih 3,9 hektar, sedangkan di Desa Mojo 54,78 hektar. Pembukaan tambak secara besar-besaran pada tahun 80an di kedua lokasi merupakan penyebab utama terjadinya kerusakan mangrove.

Berdasarkan nilai tersebut diketahui bahwa kerapatan mangrove di lokasi penelitian termasuk dalam kriteria baik. Menurut SK Men. LH No.201 tahun 2004, untuk kriteria baku kerusakan mangrove dan pedoman pemantauan kerusakan mangrove, kondisi ekosistem mangrove dapat digolongkan kedalam tiga kriteria yaitu jarang $<1000$ pohon/hektar (rusak), sedang $\geq 1000-<1500$ pohon/hektar (baik), dan sangat padat $\geq 1500$ pohon/hektar (baik).

Indeks Keanekaragaman $\left(\mathrm{H}^{\prime}\right)$ mangrove untuk kategori pohon dan sapling di Desa Mojo adalah 0,097 dan 0,199 sedangkan nilai indeks dominansinya adalah 0,576 dan 0,715 yang menunjukkan adanya dominansi. Hal itu sesuai dengan Kriteria Indeks Dominansi dari Simpson (1949) dalam Odum (1993) yang menyatakan bahwa jika nilai indeks dominansinya antara 0,5-1 $(0,5<\mathrm{D}<1)$ maka terdapat spesies yang mendominasi di wilayah tersebut.

Selain kerapatan, Indeks Keanekaragaman dan Indeks Dominansi yang paling penting untuk diketahui adalah Indeks Nilai Penting (INP). Indeks ini menyatakan kepentingan suatu jenis tumbuhan dan juga menggambarkan tingkat penguasaan jenis dalam komunitas. Indeks Nilai Penting juga memberikan suatu gambaran besarnya pengaruh dan peranan suatu jenis dalam suatu komunitas mangrove (Warongan, 2009). Berdasarkan hasil analisis data maka dapat diketahui bahwa spesies yang memiliki nilai penting tertinggi untuk kategori pohon di Desa Mojo adalah $A$. marina. Nilai penting tertinggi untuk kategori sapling di Desa Mojo adalah untuk spesies yang sama yaitu R. mucronata. Sementara nilai penting tertinggi untuk kategori seedling di Desa Mojo tidak ditemukan seedling. Menurut Warongan (2009), baik tidaknya pertumbuhan mangrove dalam suatu komunitas dapat dilihat dari analisis kondisi vegetasinya yang menunjukkan besar kecilnya peranan suatu jenis terhadap komunitas yang ada. Keadaan tersebut dapat dilihat dalam Indeks Nilai Penting yang dimiliki oleh suatu jenis mangrove. Nilai Penting yang tinggi menggambarkan bahwa jenisjenis ini mampu bersaing dengan lingkungannya dan disebut jenis dominan. Sebaliknya, rendahnya Nilai Penting pada jenis tertentu mengindikasikan bahwa jenis tersebut kurang mampu bersaing dengan lingkungan yang ada di sekitarnya serta dengan jenis lainnya. Rendahnya ketahanan terhadap gejala alam serta besarnya eksploitasi mengakibatkan jenis-jenis tersebut berkurang dari tahun ke tahun.

\section{KESIMPULAN}

Berdasarkan hasil penelitian ini dapat disimpulkan, vegetasi mangrove yang ditemukan yaitu 3 spesies mangrove berupa jenis Avicenia marina, Avicenia alba, Rhizopora mucronata. Kondisi vegetasi mangrove di Desa Mojo pada tingkat pohon didominasi oleh Avicenia marina dengan Indeks Nilai Penting (INP) sebesar 153.24. Vegetasi mangrove pada tingkat anakan didominasi oleh Rhizophora mucronata dengan Indeks Nilai Penting (INP) sebesar 171,404. 


\section{DAFTAR PUSTAKA}

Aksornkoae, S. 1993. Ecology and Management of Mangrove. IUCN. Bangkok. Thailand. 176 hal

Arikunto, 2010. Prosedur Penelitian : Suatu Pendekatan Praktek (Edisi revisi).

PT. Pemuda Cipta. Jakarta. $413 \mathrm{hlm}$.

Cintron, G., Y.S. Novelli. 1984. Methods for Studying Mangrove Structure. Snedaker, S.C. dan Snedaker, J.S., ed., The MangroveEcosystem: Research Methods.UNESCO, Paris, France. HIm: 91-113.

Curtis, J.T. 1959. The Vegetation of Wincosin, an Ordination of Plant Communities. University of Wincosin Press, Madison.

Dahuri, R. 2002. Integrasi Kebijakan Pengelolaan Sumberdaya Pesisir dan Pulau- Pulau Kecil. Makalah disampaikan pada Lokakarya Nasional Pengelolaan Ekosistem mangrove di Jakarta, 6-7 Agustus 2002.

Dahuri, R., J. Rais., S. P. Ginting., M. J. Sitepu. 2004. Pengelolaan Sumberdaya Wilayah Pesisir dan Laut Secara Terpadu. Edisi revisi. PT. Pradnya Paramita. Jakarta.

DKP Prov. Jateng. 2011. Indentifikasi Kerusakan dan Perencanaan Rehabilitasi Pantura Jawa Tengah. Dinas Perikanan dan Kelautan Propinsi Jawa Tengah, Semarang.

English, S., C. Wilkinsons and V. Baker. 1997. Survey Manual for Tropical Marine Resources. Second Edition. Australian Institut of Marine Science. Townville. 490 p.

Kennish, M.J. 1990. Ecology of Estuaries; Biological aspect. Vol II. CRC Press, Inc. New York. USA. $391 \mathrm{p}$.

Keputusan Menteri Lingkungan Hidup No. 201 Tahun 2004 tentang Kriteria baku dan Pedoman Penentuan Kerusakan Mangrove.

Kusmana, C., S. Wilarso, I. Hilwan, P. Pamoengkas, C. Wibowo, T. Tiryana, A. Triswanto, Yunasfi, Hamzah. 2003. Teknik Rehabilitasi Mangrove. Fakultas Kehutanan. Institut Pertanian Bogor. Bogor.

Mueller-Dombois, D and H. Ellenberg. 1974. Aims and Methods of Vegetation Ecology. John Wiley, London. $547 \mathrm{pp}$.

Nontji, A. 2005. Laut Nusantara (Edisi revisi). Djambatan, Jakarta.

Odum, E.P. 1993. Dasar-dasar Ekologi. Diterjemahkan oleh T. Samingan. Gajah Mada University press. Yogyakarta.

Poplawski, W.A. J. Piorewics, dan M.R. Gourlay.1989. Sediment Transport in an Inland River in Northe Queensland. Hydrobiologia Vol.176/177. Kluwer Academic Publisher. Belgium.

Supriharyono. 2007. Konservasi Ekosistem Sumberdaya Hayati di Wilayah Pesisir dan Laut Tropis. Pustaka Pelajar, Yogyakarta.

Warongan, C.W.A. 2009. Kajian Ekologi Ekosistem Mangrove untuk Rehabilitasi di Desa Tiwoho Kecamatan Wori Kabupaten Minahasa Utara Prov. Sulawesi Utara. Tesis Pasca Sarjana Institut Pertanian Bogor. Bogor.

Wilhm, J. T. dan Dorris. 1986. Fundamental of Ecology. Drenker Inc. hlm. 123125 